\title{
The Fiscal System and Objectives of GEAR in South Africa - Consistent or Conflicting?
}

\section{Mahadea}

\section{Department of Economics, University of Transkei.}

\section{ABSTRACT}

This paper critically examines the attainability of the targets set out in the South African Growth, Employment and Redistribution strategy (GEAR). The GEAR document envisaged an economic growth rate of $4.2 \%$ per annum, on average, with a rapid expansion of employment over the five-year period ending in 2000 . However, actual performance thus far falls short of GEAR projections, except for definite progress towards a reduction of the budget deficit. The current macroeconomic conditions, an over-regulated labour market, prohibitive taxation, low savings and high crime rates make it difficult to stimulate entrepreneurship and attract sufficient investment, especially of a labour absorbing nature, to meet the GEAR projections. The GEAR targets evidently need to be scaled down.

JEL H 300

\section{INTRODUCTION}

After several years of recession and low or negative economic growth rates, South Africa entered a recovery phase in 1994, registering a growth rate of $2.7 \%$ in that year, $3.4 \%$ in $1995,3.2 \%$ in 1996 and $1.7 \%$ in 1997 . But this economic revival has not been accompanied by the creation of new jobs. A process of jobless growth seems to prevail in South Africa. The unemployment situation today, at about $30 \%$ or more, and the associated poverty are worse than three years ago.

The public sector is an important employer of labour. While the public sector employment increased from 1.8 million in 1994 to 1.9 million in 1996, about 104000 employment opportunities were lost in the private sector between 1995 and 1996 (The Economist, 27/9/1997; SARB, 1997). From the end of 1996 to the end 1997, aggregate employment in the formal non-agricultural sector of the economy declined by another 130000 jobs, resulting in a situation 
in which the current total employment level is about the same as in 1981. In effect, total employment in the formal sector declined by an annual rate $1.6 \%$ in 1997 ; both the public and private sectors experienced job losses in 1997. Specifically, employment in the private sector declined by $2.3 \%$ and public sector employment, which expanded at an annual rate of $5.2 \%$ in 1996 , declined by $0.5 \%$ in 1997 (SARB, 1998).

A daunting challenge facing the new South Africa is job creation with high economic growth. Against the background of a steady decline in the labour absorption capacity of the formal sector and the need to transform the economy into a rapidly growing one, capable of attacking the problems of social transformation, unemployment and development, the government came up in mid-1996 with a "new" macroeconomic strategy: Growth, Employment, and Redistribution (GEAR).

This paper presents some economic fundamentals of GEAR and the prospects as well as limitations of GEAR to deliver on employment and growth, against the backdrop of the current South African macroeconomic situation. After the Introduction, the paper consists of five parts: the first section highlights the main elements of the GEAR strategy, the second considers alternative development strategies for South Africa, the third examines the prospects of GEAR delivering on growth and employment, the fourth looks at the limitations of the fiscal system in sustaining economic and employment growth, and the last section contains some concluding remarks.

\section{FUNDAMENTAL ELEMENTS OF GROWTH, EMPLOYMENT AND REDISTRIBUTION: A MACOECONOMIC STRATEGY (GEAR)}

A central objective of the GEAR strategy is to "catapult the economy" (1996:2) to higher levels of growth, development and employment in order to provide a "Better Life for All" South Africans. The GEAR document is related to the previously released Reconstruction and Development Programme (RDP). Thus, the Minister of Finance stated in his 1997 budget speech that "the success of the RDP is dependent on the successful implementation of the GEAR" (1997: 1). In his 1998 budget speech Minister Manuel further stressed that GEAR is one of the principal instruments for realising the policy objectives of the government within the RDP framework. "The RDP and GEAR are as much about addressing the needs of our peole today as they are about creating a strong country and economy" (1998: 1). 
GEAR is essentially an economic reform programme directed towards a competitive and fast growing economy, that would create sufficient jobs for all jobseekers, a redistribution of income and opportunities in favour of the poor, a society capable of ensuring that sound health, education and other services are available to all, and an environment in which homes are safe and places of work productive. The macroeconomic strategy aims to change the economy into a more competitive outward-oriented system, with increased emphasis on exports and investment, labour absorption, and infrastructural or service development, using labour-intensive techniques. GEAR rests on the following policy foundations:

- fiscal discipline to prevent the resurgence of inflation and to reduce the budget deficit before borrowing as a percentage of GDP, i.e. to reduce government dissaving;

- monetary discipline and relaxation of exchange controls;

- trade and industrial policy reforms, i.e. lowering import tariffs, tax and supply-side incentives to promote competitiveness, exports and investment, and the development of , micro, small and medium-sized enterprises (SMMEs);

public sector asset restructuring, i.e. privatisation;

public infrastructure and human capital investment;

greater flexibility in collective bargaining to support competitive production and a bigger role for economic factors in wage determination.

Effective policy coordination is regarded as essential for achieving the GEAR objectives. It is believed that the above measures "will establish a stable and competitive environment for significantly improved export and investment growth" (1996:5). The depreciation of the rand exchange rate especially since 1996, and more so in 1998, should make South African exports more price sensitive and elastic. In the medium term, growth is to be driven by exports, followed by a recovery in investment, and accompanied by credible economic policies and social stability. The resulting economic growth should hopefully reduce poverty and create opportunities for productive and remunerative employment.

In terms of specific targets, GEAR aims to reduce the fiscal deficit in proportion to the GDP from $5.1 \%$ in 1996 to $3 \%$ in 2000 ; to raise the increase in real GDP 
from $3.5 \%$ in 1996 to $3.8 \%$ in $1998,4.9 \%$ in 1999 and $6 \%$ in 2000 , and an increase in employment growth from $1.3 \%$ in 1996 to $4.3 \%$ in 2000 . In absolute terms, 400000 new jobs are to be created by the year 2000 and a total of 1352 000 jobs between 1996-2000. The projected objectives of GEAR and the conditions for achieving them are sound in principle, as they agree to a considerable extent with the modern approach to successful, sustainable longterm economic growth and development(De Wet and Harmse,1997:26). However, these macroeconomic targets may remain at the blueprint stage unless implemented with determination and accompanied by good governance. An important question is, then, whether the government has the capacity and ability to carry it through for several years. In the face of constraints and resistance from various quarters, as De Wet and Harmse (1997) put it, the government will "need nerves of steel" to implement the strategy over the next 5 to 10 years. It is therefore encouraging to note that, as stated by the Deputy President Mbeki in Parliament in February 1998, the government remains committed to implementing GEAR.

\section{ALTERNATIVE MACROECONOMIC STRATEGIES}

GEAR is a policy document that, if successfully implemented, may set the economy on the path to high employment and economic growth. This policy framework is broadly in line with the so-called Washington set and those that the high performing South East Asian pursued before their financial setback that commenced in the second half of 1997.

Other documents of a similar nature on South African economy have been produced in the recent past, such as the MERG report (1993), the Normative Economic Model (NEM)(1993), the IMF report (1992) "Economic Policies for a New South Africa", and the World Bank discussion paper (1994) entitled "South Africa: Economic Performance and Policies". The MERG report was in favour of a growth through redistribution policy, and in this regard the government was to have a more interventionist role in the economy to achieve redistribution and through it a faster rate of growth. On the other hand, the NEM proposed a neo-classical framework for growth, with a more prominent role to be played by the private sector. But the 1992 IMF paper, edited by Lachman and Bercuson (1992:13), stressed that for South Africa to return to an economic and employment growth path, it will need, inter alia, a substantially higher rate of domestic savings and investment than in the previous decade, to create government savings and to improve productivity, to which real wages are to be linked. However, the World Bank (1994: 15) report indicated that for a higher growth, South Africa should encourage a reorientation of manufacturing 
towards exports, emphasise job creation in small firms and agriculture, restructure government expenditure, restrict growth of recurrent spending to meet budgetary targets and maintain prudent fiscal and monetary policies. The same report further asserts that this "strategy will only be successful if there is a major revival in private investment... Direct foreign investment should be encouraged, ... and to stimulate growth the single most important ingredient is investor confidence" (1994: 15-16).

On the other hand, the South Africa Foundation (SAF) asserts that the reengineering of growth in the South African economy should rest on a strategy that focuses on enhancing savings and investment in plant and people, fiscal discipline linked to a reduction in government debt and current spending, increased competition through deregulation and privatisation of state activities, outward orientation through trade liberalisation and foreign investment, and a reform of the labour market relations that remove labour market rigidities. In short, the SAF pillars of growth are guided by a solid legal framework protecting property rights and contract enforcement, a sound macroeconomic policy, financial liberalisation, competitive markets, and an outwardly-oriented economy. Broadly speaking, GEAR seems to follow both the SAF and NEM in that they also emphasise free markets and advocate the need for flexibility of wages and prices in the labour and financial markets.

In 1997 the Africa Institute Policy Analysis (AIPA) published its "Growth with equity" framework, with an emphasis on integrating black South Africans into the mainstream economy.

In terms of its recommendations, the AIPA does not differ radically from those of GEAR in that it advocates:

- outward orientation;

- an inflow of foreign capital, encouraged by the removal of exchange controls;

- improved efficiency and competitiveness following

- enhanced skills and adoption of appropriate or improved technology;

- greater labour market flexibility;

- trade liberalisation accelerated by a depreciated rand;

- more rapid privatisation; and

- a major advance in the efficiency of social sector expenditures.

Looking at the above framework, one can notice that the GEAR document encompasses various common elements of different models. GEAR has been generally received in a favourable way; however it has also been subject to 
criticisms. For example, Pillay (1997), questions the assumptions and predictions of the model, arguing that much of GEAR emerges as "an exercise in hope and hardly forms a confident basis for a strategy of growth,employment and redistribution." To Edward Osborne (1997), GEAR relies on a "cascade of improbabilities", and recent trends in capital investment and developments in financial markets make it unlikely that employment will come anywhere near the target envisaged by GEAR in the next few years. The trade unions, especially Cosatu, are against GEAR. However, the government seems to be on course with the GEAR in general, and the framework has been described as "non-negotiable" in top policy-making circles.

\section{MACROECONOMIC CONDITIONS AND GEAR}

\section{Investment}

According to GEAR projections, real private investment should increase from about $9.3 \%$ per annum in 1996 and 1997 , to $13.9 \%$ in 1999 and $17 \%$ in 2000 , i.e. at an average annual rate of $11.7 \%$ over the period 1996-2000. In addition, real investment in the parastatals and the government sector would grow at the average annual rates of $7.6 \%$ and $7.1 \%$ respectively over the same period. Specifically, real government investment is projected to increase from about $3 \%$ in 1996 to $11.6 \%$ in the year 2000. It is estimated that an acceleration of the private and public sector investment would increase the real GDP growth from $3.5 \%$ in 1996 through $3.8 \%$ in 1998 to $6.1 \%$ in 2000 . This implies that the economy is geared to register an average annual GDP growth of $4.2 \%$ over the period 1996-2000, with the help of real growth in non-gold exports averaging $8.4 \%$ per annum, together with an expected rise in new foreign direct investment, from $\$ 155 \mathrm{~m}$ in 1966 to $\$ 804 \mathrm{~m}$ in the year 2000 . But growth in real gross domestic fixed investment actually declined from $8 \%$ in 1996 to $3.5 \%$ in 1997 (SARB, 1997).

\section{Imports, Exports and Balance of Payments}

Against the background of a rand depreciation in 1996, the GEAR strategy relies heavily on faster growth in manufactured exports to lift economic growth (from $3.5 \%$ in 1996) to $6 \%$ by the year 2000 . A shift towards exports is expected to be employment enhancing as South African exports have a higher labour capital ratio than its imports (Holden, 1992; Holden and Holden, 1980).

Further evidence from other countries shows conclusively that outward-oriented trade policies are conducive to rapid economic growth, as they promote 
competition, encourage learning-by-doing, improve access to trade opportunities, raise productivity and enhance positive externalities resulting from modern technology (Dollar, 1992; Edwards, 1993; World Bank, 1993; World Development Report, 1995). Manufactured merchandise exports as a proportion to GDP have consistently increased from $18 \%$ in $1993 / 94$ to $23 \%$ in 1997 (SARB,1997). While the depreciation of the rand should make South Africa's manufactured exports more competitive, a significant part of this price effect might be dissipated by higher costs of imports. On the other hand, South Africa's gold production declined from 619 tons in 1993 to 485 tons, resulting in a fall in employment, in the first half of 1997, owing partly to rising costs of extraction and a fall in the price of the metal.

Furthermore, while the inflation rate had fallen from $9 \%$ in 1994 to $5 \%$ in (April) 1998, partly thanks to the tight monetary policy of the Reserve Bank, the import penetration ratio (ratio of imported goods at constant prices to total real gross domestic expenditure) increased from $19 \%$ in 1993 to $28.5 \%$ in the fourth quarter of 1997. Despite a relatively modest growth in exports, the negative current account on the balance of payments deteriorated from R1.2 billion in 1994 to R8.8 billion in 1997 (SARB, 1998). Net capital inflows remained insufficient to cover the current account deficit, thus resulting in a decline in net gold and foreign reserves. In effect in 1997, net reserves contracted from R12.7 billion in the second quarter to R2.1 billion in the third quarter (SARB, 1997). While GEAR envisages an economic growth rate of $6 \%$ in year 2000 , it should be stressed that growth is likely to give rise to unsustainably large deficits on the current account of the balance of payments in view of the South African high propensity to import. Hence, the rising deficit on the current account is likely to constrain the speed at which new investment, and hence growth and employment can be accelerated during the immediate years before 2000 .

\section{Fiscal Discipline}

GEAR envisages that fiscal discipline will be exercised. The objective is to reduce government consumption expenditure relative to GDP and to reduce the fiscal deficit from $5.1 \%$ in 1996 to $3 \%$ in 2000 . Large and persistent fiscal deficits crowd out the wealth-creating capacity of the private sector, and lead to inflation and balance of payments difficulties. The exercise of fiscal prudence is stressed by the need to impart credibility, stability and consistency to government policy. Otherwise wrong signals would be sent to markets, which in turn harm investor confidence and adversely affect capital inflows. The GEAR document holds that a declining fiscal deficit will lead to falling rates of interest, that in turn would support expected rise in private investment. If one compares the fiscal deficit of $8.6 \%$ of GDP in 1992/93 against the current 
deficit of about $4 \%$ in $1997 / 98$, there is a definite trend towards reduced deficits. One might plausibly argue that this is the greatest success that GEAR has achieved thus far.

The servicing of the public debt is an expensive component of government spending. The cost of servicing state debt in South Africa increased from $5.9 \%$ of GDP in 1995/96 to $6.4 \%$ in $1997 / 98$. The interest cost of debt servicing is thus a continuous drain on the country's resources; absorbing $21 \%$ of the total government expenditure in 1997/98, making it the second largest category of spending after education at about $25 \%$. Of the R201 billion budgeted expenditure for 1998/99, only R159 billion is available for spending; the rest goes to meet the cost of state debt. This suggests that future reductions of the debt burden should enable the government to augment the spending on its social ends without necessarily creating fiscal pressures.

The expected reduction in budget deficit to 3.5\% of GDP in 1998/99 and more sharply to $3 \%$ in the following year as per GEAR, would adversely affect some of the services provided by the national and provincial authorities. A case in point is the current crisis in many schools and universities, resulting largely from a budget cut by the government. Clearly, this would generate a generally contractionary situation, whereby the growth of some welfare or essential services may be negatively affected, let alone the adverse impact on employment in the public sector.

Moreover, several promises have been made to the electorate on the delivery of socio-economic services designed to improve the quality of life of the citizens. As the election year 1999 approaches, populist measures might be adopted; and in that electioneering context government expenditure might then be increased rather than reduced. Overall, it seems unrealistic to believe that it will be possible to reduce the fiscal deficit to $3 \%$ by 2000 , and at the same time increase real government investment expenditure by $7.1 \%$ on average over the GEAR period. Any significant reduction of the fiscal deficit would probably require a strong growth in state revenue. Revenue from the sale of public assets might help to boost the state coffers. The progress of privatisation has thus far been rather slow, as only Sun Air, a domestic air line and a segment of Telkom have been sold off. The 1998 budget does not make any direct reference to privatisation, but recent positive statements by the government suggest that the pace of asset sales might increase. In spite of these asset sales, the growth in government revenue actually declined from $14.2 \%$ in the first half of the fiscal year to $8.9 \%$ in $1997 / 98$. On the other hand, in the first half of the fiscal year $1997 / 98$ there was also a sizable disparity between government expenditure and revenue, resulting in a net deficit of R19 billion (SARB, 1997). As a percentage of GDP, this deficit came to $6.4 \%$, which is indeed much higher than the $4 \%$ for 
the fiscal year 1997/98 envisaged by GEAR. The financing of this R19 billion deficit by government borrowing contributed to an increase in the public debt from R310.6 billion to R336.1 billion over the 9-month period ending December 1997. This implies that total debt as a percentage of GDP increased from $55.8 \%$ in March to $56.5 \%$ in December 1997 (SARB, 1998).

\section{Monetary Policy}

Linked to fiscal policy is monetary policy, an important instrument of which is the interest rate. GEAR advocates a policy of high real interest rates, an average real prime rate of $7.9 \%$ and a real bank rate of $4.4 \%$ over the $1996-2000$ period. A policy of high interest rates is helpful in attracting foreign capital and to generate savings. Thus, in his budget speech (1997: 3) the Minister of Finance stated that "we need to compete to attract savings from elsewhere in the world", and this year he further stressed that since "we do not generate sufficient domestic savings to finance the levels of investment we need, we must attract foreign savings" (1998: 9). GEAR's target is to raise private savings in relation to GDP ratio from $20.5 \%$ in 1996 to $21.9 \%$ in 2000 .

In the Classical approach, savings are directly related to interest rates and investment is inversely related to interest rates. Thus, with low interest rates we expect higher investment, which via the multiplier effects, lead to higher income, output and employment. These in turn generate higher savings. High real interest rates might attract capital inflows and suppress inflation but, more damaging, they could make the cost of borrowing capital for investment purposes prohibitive. This is all the more true for the micro and small firm entrepreneurs, who are trying to create jobs for themselves and others under conditions of financial constraints. Hence, what is needed for promoting investment and employment creation are lower interest rates than those during the past few years.

In terms of the Harrod-Domar model, the real economic growth of an economy is directly related to its savings rate and inversely to the capital-output ratio. If one assumes an optimistic investment-incremental capital output ratio (investment divided by the additional GDP associated with it) of 5 , then South Africa needs to invest $30 \%$ of its GDP to achieve a real growth of $6 \%$ as set by GEAR (Edwards, 1997). But the actual investment in 1997 at about $17 \%$ of GDP is well below the desired $30 \%$. This is clearly too low to meet the growth, employment and development needs of South Africa.

A prerequisite for the growth and employment objectives is the creation of an investment friendly climate. To raise capital formation in the spirit of GEAR, 
the government recently introduced various supply-side and tax incentives. Existing manufacturers, for example, are allowed with effect from October 1996 to depreciate new plant and equipment over 3 instead of 5 years, and to write off new buildings used in manufacturing at $10 \%$ per annum instead of $5 \%$. An accelerated depreciation allowance and easier access to finance is offered for the formation or expansion of small, medium and large enterprises with assets of R3 million or less. The government is also encouraging various investment projects in partnership with the private sector, such as the Maputo development corridor and the Wild Coast (East London - Port St Johns) spatial development initiatives. Exchange controls have been partially relaxed since July 1997 and were further relaxed in March 1998. While these efforts are bold and commendable, it is questionable whether it will be possible to maintain conditions conducive to attract substantial inflows of capital and to appreciably speed up investment for the creation of new jobs on a scale projected in the macroeconomic strategy.

\section{Labour Flexibility}

GEAR rèlies considerably on labour market flexibility for its delivery. A lack of market flexibility is a major cause of unemployment. But the government's the Basic Conditions of Employment Act, affirmative action and the payroll levy legislation will impose rigidities that will price more jobs out of the labour market. Such regulation not only constrains the hiring of labour, but affects factor substitution and mobility of capital, and these run counter to the tenets of GEAR.

\section{Savings and Foreign Direct Investment}

Fast economic growth cannot be imported; it must be generated mainly at home. The experiences of the East Asian economies indicate that their average annual growth rates of over $8 \%$, for almost three decades, were rooted in wise government policies and attracting large inflows of foreign direct investment. These capital inflows served to supplement their own high level of internal savings (The Economist, 1/3/97). So it is vital for South Africa, too, to attract more foreign investment to reach growth and employment targets as set in GEAR. Now that apartheid is gone and a new democratic government is in place, South Africa should, in principle, be in position to attract substantial amounts of foreign capital. But South Africa has been able to attract only some $0.1 \%$ of the world's foreign direct investment (FDI). According to Unctad's World Investment Report (1997) South Africa received around $\$ 330$ million over the previous 3 years in FDI, whereas South East Asia received \$81 billion in 1996. Clearly, the actual amount of FDI in South Africa compares poorly 
with the average annual figure of $\$ 509$ million that it is targeted to receive in terms of GEAR.

A closer look at the experience of the East Asian Tigers reveals that the (pre1998) growth of these economies were driven by high savings and investment ratios as well as by high imports and exports. These were cases of growth-led exports more than cases of export-led growth. Domestic savings and investment were the driving elements, with external savings and FDI providing supplementary support. The direction of the growth force was from inside outward, rather than outside-inward (Bradford, 1997). This implies that South African households and firms need to channel domestic resources towards investment as the necessary trigger for international investment, rather than rely on foreign capital or foreign trade as the motor for growth.

The savings record of South Africa is rather low, partly on account of government dissaving and high taxation. The current low saving rate is a structural impediment to sustained, investment-driven, output and employment growth. In effect, gross domestic saving as a percentage of the country's GDP declined from $16.9 \%$ in 1995 to $16.5 \%$ in 1996 , and to about $14.5 \%$ in the first quarter of 1998 (SARB, 1998). Yet in terms of GEAR, the government is aiming for an annual gross private saving rate of around $20.5 \%$ of GDP. It is estimated that with a cut in government's dissaving and a boost in the level of private savings, overall savings rate would be close to $22 \%$ of GDP. Even with an optimistic savings rate of $22 \%$ by the year 2000 , South Africa will require substantial capital inflows from abroad to finance the shortfall in its projected investment requirements. GEAR assumes that foreign financing will be equivalent to about $4 \%$ of GDP. Even though South Africa has a relatively low external debt, it seems unlikely that it can attract such a scale of foreign capital for its growth and employment needs. There is an exaggerated and uncritical view of the importance of foreign capital to South Africa's economic development (Padayachee, 1997). Excessive reliance on foreign borrowed capital could develop into unsustainable growth in foreign debt, which in turn would demand increasing servicing costs. Rising debt would have intergenerational debt repayment implications, with the present generation imposing debt burdens on future generations.

It should not be overlooked that in the era of globalisation and intense competition, firms invest, and jobs are created, on the prospect of returns. Capital flows to regions where retums to investment are substantial and there is security of property rights, good governance and stability. Corruption, robbery and crime in general are on the rise in South Africa. Some services in certain provincial administartions seem close to collapse, and the murder rate remains 
among the highest in the world; "... today, of all the threats to South Africa's stability the most serious is probably .... violent crime" (The Economist $13 / 12 / 97$, p.18). These perceptions, or realities, lead not only to a misallocation of resources, but have a detrimental effect on actual and potentail investors' willingness to invest in the country.

In its bid to attract foreign and encourage domestic investment, South Africa will also have to address the issue of poor work ethic, productivity and competitiveness. Poor competitiveness impinges on trade and job creation. The World Competitiveness Yearbook ranks South Africa in the 45th place, second to last amongst 46 countries, and the ranking for SA management dropped to the 43rd position in 1997 from the 40th in 1996 and 38th in 1995. These perceptions obviously do not make South Africa a suitable area for long term foreign investment, with other countries vigorously competing for capital.

The insufficiency of household saving limits the availability of funds for investment and consumption of durables. In the Keynesian framework, saving and consumption are mainly a function of income, net of tax. As real disposable income increases, saving and consumption increase too. High interest rates may influence households to increase their saving by substituting future consumption for current consumption, in response to the higher rewards for saving. Recent evidence from research by the IMF and others on the intertemporal elasticity of substitution, indicates that elasticity actually falls as interest rates rise higher than 3 per cent (Pill, 1997; Ostry and Reinhart, 1995). Indeed, according to the McKinnon-Shaw hypothesis (1973), repression of the domestic financial system in the form of interest ceilings, directed credit programmes and other forms of government interventions in the domestic capital markets, especially the banking system, hinder economic growth. This implies that low positive real interest rates may have a minor effect on encouraging personal saving; hence, one cannot rely on variation of interest rates as an effective measure for augmenting national saving in South Africa.

\section{TAXATION}

The saving and consumption as well as investment problems in South Africa may also be examined in the context of the country's overall tax system. Government expenditure needs to be financed mainly out of tax revenue and by public sector borrowing. Real government consumption expenditure as a percentage of the country's GDP, has increased from $20.5 \%$ in 1996 to $21 \% .5$ in 1997 (SARB, 1997), and to $22 \%$ in the first quarter of 1998 (SARB, 1998), thus leaving fewer resources for the private sector. In effect, such a growth in 
consumption expenditure by the government is well in excess of the GEAR projected ratio of $19.5 \%$ for 1997 and $18.1 \%$ for year 2000 . It is true that owing to the legacy of apartheid, considerable backlogs have to be addressed in the provision of essential services. The government is spending about $22.5 \%$ of its $1997 / 98$ budget on basic social services, education, health care, water, and welfare, but about three fifths of the earmarked funds are spent on debt and salaries, leaving very little scope for capital investment. Social welfare is an item on which government will have to spend more money in the future. One might well ask how far can the government reprioritise its expenditure to meet a rising welfare bill without sacrificing other expenditures.

Turning to the private sector, in recent years households have resorted increasingly to debt financing at high interest rates to support their average propensity to consume, as their income after tax leaves them with little prospect of maintaining accustomed living standards. This is evidenced by the rapid growth of total household debt in relation to personal disposable income, from less than $60 \%$ in 1994 to almost $69 \%$ in (June) 1997 (SARB, 1997). Accordingly, the debt servicing ratio of private households has increased from less than $10 \%$ in 1994 to about $14 \%$ in 1997 . This means that approximately $14 \%$ of household disposable income is spent just for the payment of interest on household debt. On top of this, a high proportion of the households' hardearned income is being absorbed by prohibitive direct and indirect taxation. South Africa's marginal tax rate of $45 \%$ on individual income earners of R120 000 or more compares unfavourably with its neighbours and is regarded as being too high. The middle-income South African with an annual income of R120 000 must work for 4 months in a year just to pay his tax bill, whereas his counterpart in the U.K, earning $£ 25000$ a year would spend only 92 days to settle his income tax bill, and in the USA, someone earning $\$ 80000$ (equivalent to about 500000 rands!) would give up just under 70 days' work to settle his income tax bill (Sunday Times, 1/9/96). Recent ,conservative estimates by $\mathrm{N}$. Czypionka (1998) indicate that for an individual with an annual income of R140 $000,55 \%$ of his earnings is absorbed by direct, indirect and quasi-taxes, and for someone eaming a yearly income of R75 000 the total tax burden is $45 \%$ (Sunday Times, 5/4/98). In addition, the average household has to pay a host of other taxes that impinge on its consumption, savings and investment, such as the fuel levy, various rates, security costs and municipal tax. In return, one should expect the households in South Africa to enjoy certain basic services, such as security protection, adequate health care and proper education.

Further, South Africa's corporate tax of $35 \%$ does not compare well with neighbouring countries, such as Botswana, having a corporate tax rate of only $25 \%$, and the OECD countries with a tax rate, on average, of $33 \%$ (The 
Economist, 20/9/1997). Another heavy blow to domestic saving and consumption is the sales or value added tax. South Africa's value added tax at $14 \%$ compares unfavourably with countries such as Botswana (10\%), Namibia $(8-11 \%)$ and Swaziland (12\%). The principle of taxation is understandable, as the government needs to earn revenue to finance its expenditure and meet redistributive needs. Redistribution on a large scale is however possible to the extent that the economy registers high growth and the national product grows in proportion to the population.

The tax burden on the average South African is already too high and the imposition of further taxes would no doubt dull incentives and may even generate less revenue. As the authors of an IMF study on South Africa stated, "the overall South African tax burden and its marginal tax rates cannot be judged to be low by international standards; indeed the tax burden ... appears to be relatively high even by industrial country standards. This would argue against raising tax rates in South Africa and running the risk of heightening disincentive effects" (Lachnman and Bercuson,1992:2). Taxes, even though they pay for worthwhile public goods and services, impose an inescapable economic burden, the so-called deadweight loss, and this cost rises more than proportionately as taxes go up (The Economist, 20/9/97). Hence, the solution is clear: if the government tries to produce or offer too many things, it is likely to do so at rapidly diminishing returns. At low levels of government activity, the deadweight cost of taxes may well be outweighed by the gains that flow from essential public goods. Therefore, in the domestic context, if South Africa is to attain faster rate of growth in employment and output, the government should reduce spending and cut marginal tax rates at all levels of income. These tax cuts have led to an economic boom virtually everywhere they have been tried.

The U.K, for example, cut its top tax rate on earned income from $83 \%$ in 1979 to $40 \%$ in 1986 , and as a result annual economic growth in Britain, which was on average only $1.2 \%$ for over 10 years, shot up to $4 \%$ between 1985 and 1989 . Likewise, after Turkey slashed its top rate from $75 \%$ to $50 \%$, and its minimum rate from $40 \%$ to $25 \%$, its average annual economic growth jumped to nearly $7 \%$ in $1986-1989$, and to $9 \%$ in 1990 . South Korea reduced the top rate from $70 \%$ in 1981 to $55 \%$ in 1984 , and the bottom tax rate from $8 \%$ in 1981 to $6 \%$ in 1982 , and enjoyed an average economic growth rate of $8 \%$ between 1981 and 1989, and 7.7\% between 1990 and 1996 (The Economist, 1/3/97). The lesson to be learnt from the growth experiences of other countries that have made an economic breakthrough, is that a major obstacle to high employment and national prosperity is heavy government intervention, through high taxes, unnecessary price controls, lavish government spending and regulation of the market, particularly the labour market. Therefore, if South Africa is to be put 
on a significantly higher employment and growth path, the government should have the courage to deregulate the labour market, reduce tax at all levels of income and cut unproductive public expenditure to the maximum extent possible.

\section{CONCLUSION}

The growth, employment and redistribution challenges facing South Africa are formidable and intricate. The legacy that the apartheid system bequeathed to the new democratic government is indeed burdensome. Thus the present government inherited considerable backlogs of housing, education, employment and basic socio-economic needs. These backlogs cannot be redressed unless appropriate strategies are implemented in a rapidly growing economy. Hence, GEAR aims to transform the economy into a fast- growing one, capable of providing jobs and a better life for all South Africans. Although the economy has been in an upswing phase for the past four years, this has not been robust enough to meet the GEAR growth or employment targets.

Perhaps some progress has been made towards the target of the $6 \%$ growth rate by the year 2000 , but the prospect of creating some 400000 new jobs by then has become increasingly remote. Progress has been particularly lacking in the area of labour market flexibility. Instead of removing rigidities, new labour legislation might well encourage factor substitution and discourage firms from hiring labour. Nevertheless, the budget deficit seems on a definite downward trend. Inflation has also been declining, giving scope for lower interest rates and perhaps a boost to domestic investment. The coming Presidential summit on job creation might assist in developing policies relating to GEAR's vision of an increase in the labour absorption capacity of the economy. What is further required, is an institutional and fiscal mechanism to encourage savings and promote investment. Of particular significance is a sensible fiscal policy with the effect of reducing unproductive public expenditure and cutting taxation. Economists from the days of Adam Smith through Schumpeter to Laffer have, with reason, stressed that high taxes undermine economic growth, ultimately producing less public revenue than what the government might have collected from low taxes. Reduced marginal tax rates should encourage people to venture into entrepreneurial activities and to work harder, which in turn would boost work effort and productivity. Tax cuts also promote business formation and expansion, as firms would find it easier to finance their investment with internal funds. To quote a prominent economist, who also became an influential finance minister of the Austrian government: "Any tax on net earnings will tend to shift the balance of choice between 'to do and not to do' a given thing.... and, 
therefore, taxes beyond a percentage that greatly varies as to time and place must blunt the profit motive." (Schumpeter, 1934: 291-292). Punitive levels of taxation reduce our capacity to save, invest and generate jobs.

\section{REFERENCES}

1. AIPA (1997):Growth with Equity, Aipa (Africa Institute for Policy Analysis)/Francolin Publishers, Cape Town

2. BRADFORD, C. I (1997): Growth with Equity: South Africa's Challenges,Paper presented at AIPA's International Conference on Growth with Equity in South Africa,September 17, Victoria and Alber Hotel, Cape Town.

3. De Wet, G. L. and HARMSE, C. (1997): An Appraisal of the RDP and the Macroeconomic Strategy of the South African Governmentin terms of Conditions of Sustainable Economic Growth and Development, South African Journal of Economic and Management Sciences, Vol 21: 18-29 (Autumn).

4. DOLAR, D. (1992): Outward-Oriented Developing Economies Really Do Grow More Rapidly: Evidence from 95 LDCs, 1976-1985, Economic development and Cultural Change, Vol 32 (April): 523-544.

5. EDWARDS, C. (1997): Savings, investment and the development of the South African economy: how can the rate of economic growth be raised?

6. Paper presented at the UDW/Mecury/Coastal Inernational Conferenece, Durban, April 24.

7. EDWARDS, S. (1993): Openess, Trade Liberalization and Growth in Developing Countries, Journal of Economic Literature, Vol. 31(September): 1358-93.

8. FALLON, P. and DE SILVA, South Africa: Economic Performances L. A (1994): and Policies, The World Bank, Washington, D. C.

9. GEAR (1996): Growth, Employment and Redistribution: a Macroeconomic Strategy, Department of Finance, Pretoria.

10. HOLDEN, M. (1992): Trade Reform: Finding the Right Road, The South African Journal of Economics, Vol 60, No 3: 249-262.

11. HOLDEN, M. and HOLDEN, P. (1980). The Employment Effects of different Trade Regimes in South Africa, The South African Journal of Economics, Vol 44, No 3: 232-240.

12. LACHMAN, D. and BERCUSON, K. (eds.) (1992). Economic Policies for a New South Africa, Washington, IMF.

13. MERG (1993): Making Democracy Work: A framework for Macroeconmic Policy in South Africa, Macroeconomic Group (MERG), Centre for Development Studies, Cape Town. 
14. OSBORN, E. (1997):Fiscal and Monetary Policy and the Gear, Paper presented at the UDW/Mercury International Conference, Durban, 24 April.

15. OSTRY, J. and REINHART, C. (1995): Saving and the Real Interest Rate in Developing Countries, Finance and Development, (December 1995): 18.

16. PILL, H. (1997). Real Interest Rates and Growth: Improving on Some Deflating Experiences, The Journal of Development Studies, Vol 34, No 1,85-110.

17. PILLAY, V. (1997). The Budget, Gear, and the Emasculation of the Role of the State in the National Economy, Paper presented at the UDW/The Mercury International Conference, Durban, 24-25 April.

18. SAF (1996): Growth for All: an Economic Strategy for South Africa, South African Foundation. Johannesburg.

19. SARB (1998). South African Reserve Bank Quarterly Bulletins, No 207 208., Pretoria.

20. SARB (1997). South African Reserve Bank Quarterly Bulletins, No 203206, Pretoria.

21. SARB (1997). Annual Economic Report, Pretoria.

22. SCHUMPETER, A. J (1939). Business Cycles, Vol 1, McGrawHill, NY.

23. SUNDAY TTMES (1996). Taxed to Debt, 1 September.

24. SUNDAY TIMES (1998). You are a Civil Servant until Lunchtime, Slaving for Tax, 5 April.

25. THE ECONOMIST(1997). The Asian Miracle, March 1, 23-25.

26. THE ECONOMIST (1997). A Survey of the World Economy, September 20, $19-21$.

27. THE ECONOMIST (1997). South Africa: The End of the Miracle?, December 13, 17-18,22.

28. UNCTAD (1997). World Investment Report, NY.

29. WORLD BANK, (1993). The East Asia Miracle: Economic Growth and Public Policy, OUP, Oxford.

30. WORLD DEVELOPMENT Workers in an Integrating World, REPORT (1995). OUP, Oxford. 